\title{
Regional analysis of groundwater nitrate concentrations and trends in Denmark in regard to agricultural influence
}

\author{
B. Hansen ${ }^{1}$, T. Dalgaard ${ }^{2}$, L. Thorling ${ }^{1}$, B. Sørensen ${ }^{1}$, and M. Erlandsen ${ }^{3}$ \\ ${ }^{1}$ Department of Groundwater and Quaternary Geology Mapping, Geological Survey of Denmark and Greenland - GEUS, \\ Lyseng Allé 1, 8270 Højbjerg, Denmark \\ ${ }^{2}$ Department of Agroecology, Aarhus University, Denmark \\ ${ }^{3}$ Department of Public Health, Aarhus University, Denmark
}

Correspondence to: B. Hansen (bgh@geus.dk)

Received: 3 April 2012 - Published in Biogeosciences Discuss.: 4 May 2012

Revised: 5 July 2012 - Accepted: 8 July 2012 - Published: 23 August 2012

\begin{abstract}
The act of balancing between an intensive agriculture with a high potential for nitrate pollution and a drinking water supply almost entirely based on groundwater is a challenge faced by Denmark and similar regions around the globe. Since the 1980s, regulations implemented by Danish farmers have succeeded in optimizing the $\mathrm{N}$ (nitrogen) management at farm level. As a result, the upward agricultural $\mathrm{N}$ surplus trend has been reversed, and the $\mathrm{N}$ surplus has reduced by $30-55 \%$ from 1980 to 2007 depending on region. The reduction in the $\mathrm{N}$ surplus served to reduce the losses of $\mathrm{N}$ from agriculture, with documented positive effects on nature and the environment in Denmark. In groundwater, the upward trend in nitrate concentrations was reversed around 1980, and a larger number of downward nitrate trends were seen in the youngest groundwater compared with the oldest groundwater. However, on average, approximately $48 \%$ of the oxic monitored groundwater has nitrate concentrations above the groundwater and drinking water standards of $50 \mathrm{mg} \mathrm{l}^{-1}$. Furthermore, trend analyses show that $33 \%$ of all the monitored groundwater has upward nitrate trends, while only $18 \%$ of the youngest groundwater has upward nitrate trends according to data sampled from 1988-2009. A regional analysis shows a correlation between a high level of $\mathrm{N}$ surplus in agriculture, high concentrations of nitrate in groundwater and the largest number of downward nitrate trends in groundwater in the livestock-dense northern and western parts of Denmark compared with the southeastern regions with lower livestock densities. These results indicate that the livestock farms dominating in northern and western parts of Denmark have achieved the largest reductions in $\mathrm{N}$
\end{abstract}

surpluses. Groundwater recharge age determinations allow comparison of long-term changes in $\mathrm{N}$ surplus in agriculture with changes in oxic groundwater quality. The presented data analysis is based on groundwater recharged from 1952-2003, but sampled from 1988-2009. Repetition of the nitrate trend analyses at five-year intervals using dating of the groundwater recharged in the coming years and a longer time series of the nitrate analyses can reveal the evolution in nitrate leaching from Danish agriculture during the past $10 \mathrm{yr}$. Similar analyses can be carried out to compare with other regions internationally.

\section{Introduction}

Intensive agriculture is a major source of environmental $\mathrm{N}$ (nitrogen) pollution with severe $\mathrm{N}$ losses to soil, water and air. The environmental effects include a decline in biodiversity, eutrophication of ecosystems and surface waters, acidification, global warming, air pollution and diffuse nitrate pollution of groundwater. $\mathrm{N}$ pollution from intensive agriculture not only affects the environment, but may also affect human health due, for example, to the presence of $\mathrm{N}$-containing particles in the atmosphere, which may give rise to respiratory health problems and diseases, or nitrate in drinking water, which may pose risks for some types of cancer, although no firm conclusions exist (van Grinsven et al., 2010; Erisman et al., 2011).

The manufacture of nitrogen-containing fertilizer for food production and the cultivation of leguminous crops convert 
atmospheric $\mathrm{N}_{2}$ into reactive forms that significantly perturb the global nitrogen cycle and threaten the stability of the planet (Rockström et al., 2009). Globally, industrial N fixation has increased exponentially from near zero in the 1940s (Vitousek et al., 1997). The production of nitrogen fertilizers has been the main reason for the increase in world crop productivity, thus supporting the human population growth, but nitrogen fertilizers also cause $\mathrm{N}$ imbalances in agricultural development in all parts of the world (Vitousek et al., 2009).

A global challenge is to produce enough food for the evergrowing population and at the same time minimizing the loss of $\mathrm{N}$ to the environment. Since the 1980s, agriculture in Western Europe has managed to reduce its nitrogen surpluses, owing to stringent national and European community policies (Vitousek et al., 2009; Grizzetti et al., 2011; Hansen et al., 2011; Dalgaard et al., 2012). However, Vitousek et al. (2009) reckon that regions in Africa continue to extract the nutrient capital of what were once highly fertile soils with low yields, while in contrast intensive agricultural production in Northern China has a very high input of $\mathrm{N}$ to agricultural fields and high yields, but also a very high $\mathrm{N}$ loss to the environment.

Nutrients in the soil are leached when the supply exceeds the nutrient demand of the plant. Since 1980, agriculture in Denmark has been able to reduce its $\mathrm{N}$ surplus by approximately $40 \%$ while maintaining crop yields. The result of the reduction in the agricultural $\mathrm{N}$ surplus is reflected in respective reductions in nitrate leaching of on average $33 \%$ (Kronvang et al., 2008), the $\mathrm{N}$ load in surface waters of approx. 29-32\% and groundwater nitrate concentrations of approx. $40 \%$ (Hansen et al., 2011). Also other countries such as The Netherlands (Visser et al., 2007), Belgium (Aguilar et al., 2007) and the US (Rupert, 2008; Burow et al., 2010) have observed effects on groundwater nitrate concentrations due to impact from fertilizer use in agriculture. Several Danish initiatives have been taken to reduce the $\mathrm{N}$ pollution from agriculture. Some of the most effective environmental measures have been a reduction in the statutory and crop-specific $\mathrm{N}$ fertilisation standards and $\mathrm{N}$ utilization requirements of manures which has raised the overall $\mathrm{N}$ use efficiency from $27 \%$ in 1985 to $40 \%$ in 2008 (Dalgaard et al., 2011a).

In Denmark, public drinking water supplies almost entirely originate from groundwater and approximately $15 \%$ of the total area of Denmark has therefore been classified as nitrate-vulnerable abstraction areas (Hansen and Thorling, 2008) with many waterworks and wells having been turned off due to nitrate pollution. Groundwater protection is therefore a high priority, and since 1985 it has been one of the most important drivers of regulation of the Danish agricultural sector through national action plans (Kronvang et al., 2008) and EU policies (Uthes et al., 2011; Happe et al., 2011).

The present paper continues the analysis initially presented and published in Hansen et al. (2011). The focus is still on nitrate in the oxic zone of the Danish groundwater, because we are examining the effect of nitrate leaching on groundwater nitrate concentrations. In oxic Danish groundwater, it can been assumed that nitrate leached to groundwater acts as a conservative compound under the presence of oxygen and the generally low reactivity of organic matter below the root zone. The aims of the present study are to better understand the geographic distribution of nitrate in groundwater and the evolution of nitrate trends in Denmark at different groundwater recharge ages by examining the influence from (1) regionally calculated $\mathrm{N}$ losses from agriculture and (2) the local amount of groundwater recharge.

\section{Methods}

\subsection{Agricultural, geological and hydrological conditions}

Denmark has a total land area of about $43000 \mathrm{~km}^{2}$, and about two-thirds of this is under agricultural use. The fertilization rate in Denmark is high compared with other European countries (OECD, 2010; European Environmental Agency, 2005). The average livestock density is about 0.8 livestock units per hectare (Dalgaard et al., 2011b), and the average input of $\mathrm{N}$ to agricultural land was about $180 \mathrm{~kg} \mathrm{ha}^{-1} \mathrm{yr}^{-1}$ in 2008 (Statistics Denmark, 2010; Kronvang et al., 2008). The land surface has a modest topography where the highest point is $170 \mathrm{~m}$ above sea level. The climate in Denmark is coastal temperate, and the precipitation varies from about 600 to $1000 \mathrm{~mm} \mathrm{yr}^{-1}$. The upper geologic layers are mainly 50-200 m thick Quaternary glacial deposits underlain by Tertiary marine and fluvial deposits or Cretaceous limestone and chalk. The aquifers thus consist of either unconsolidated sands and gravels or fractured limestone and chalk.

\subsection{Nitrate reduction in Danish groundwater}

The Danish groundwater can be divided into an upper oxic zone and a, usually, deeper reduced zone (Fig. 1). Nitrate reduction takes place in an intervening zone, called the nitratecontaining anoxic zone, between the oxic and the reduced zones. The redox interface divides the upper nitrate containing zones from the reduced zone. Hydro-geological heterogeneity and variation in the reduction capacity of the sediments can locally result in a complex transition between the oxic and the reduced zones (Hansen and Thorling, 2008). These circumstances also give rise to variation in the thickness of the anoxic zone from a few mm to more than $15 \mathrm{~m}$ across the country. In Denmark, the oxic zone in the Quaternary deposits has developed after the latest glaciations. On exposed residues of Saalean landscapes in western Denmark, the oxidation processes have been active for more than $100000 \mathrm{yr}$, whereas, in the rest of the country, they have only been active for about $12000 \mathrm{yr}$ due to differences in the extension of the latest glaciations.

Nitrate reduction in the soil and groundwater is often microbially controlled. In the unsaturated zone, the 


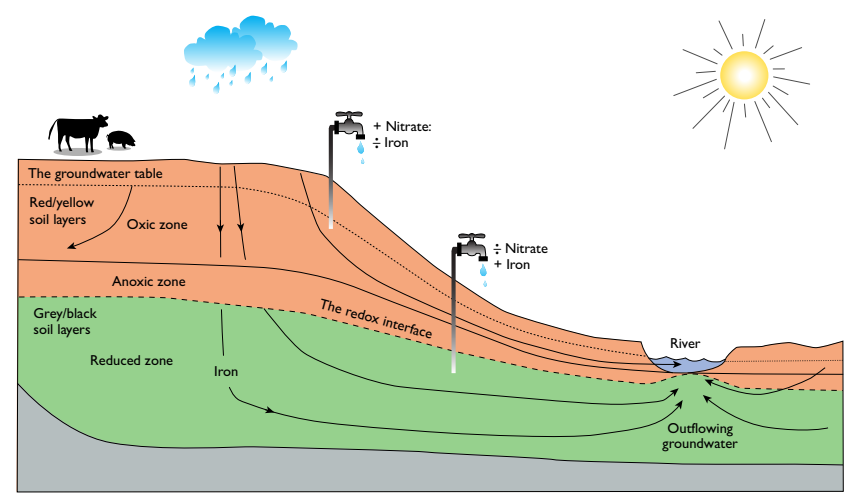

Fig. 1. Conceptual model of the typical groundwater redox environment in Denmark with oxic zone, anoxic zone with nitrate reduction and reduced zone. The interface between the anoxic zone containing nitrate and the reduced nitrate-free zone is called the nitrate interface and can also be determined based on the colours of the sediments. Above the nitrate interface, the soil layers have red and yellow colours, and below the nitrate interface the soil layers have grey and black colours.

denitrification processes take place in the reduced microenvironments due only to reduction of organic matter (Ernstsen, 1999). In the groundwater aquifers, organic matter, ferrous ions and pyrite (Postma et al., 1991) are the dominating nitrate-reducing agents causing the denitrification processes that take place in the nitrate-reducing anoxic zone.

\subsection{Nitrate concentrations in oxic groundwater}

Different type of nitrate data has been used in the statistical analyses of nitrate in Danish groundwater according to the purposes which are summarized in Table 1. Data on nitrate concentrations from all types of wells (monitoring, investigations, abstraction, etc.) have been integrated to obtain a national overview of the geographic distribution of the nitrate in oxic groundwater in Denmark set out in Fig. 2a. Like many other data used for chemical analyses of the Danish groundwater, nitrate concentrations are being reported to the national database JUPITER. Totally, there are 162144 nitrate analyses sampled from 1890-2011. The data used in Fig. 2 were downloaded in January 2011 and consist of 3757 oxic monitoring points with average nitrate concentration based on 11518 analyses sampled in the period 1967-2011. Data from such a long period are used in order to obtain as many nitrate analyses as possible from the oxic zone to create a national overview. Data stored in JUPITER have been analyzed by professionally certified laboratories.

Before nitrate concentrations are determined in the laboratories, the groundwater samples undergo normal analysis in the field which includes online measurements of $\mathrm{pH}$, redox potential, oxygen concentration, temperature and conductivity. This approach ensures a high analytical quality and representative groundwater samples. Performing field analy-
Table 1. Data used in the statistical analyses of nitrate in Danish groundwater.

\begin{tabular}{llll}
\hline & $\begin{array}{l}\text { All types } \\
\text { of wells }\end{array}$ & \multicolumn{2}{c}{$\begin{array}{c}\text { Danish Groundwater } \\
\text { Monitoring Programme }\end{array}$} \\
\hline $\begin{array}{l}\text { Total amount of } \\
\text { nitrate analyses }\end{array}$ & 162144 & 46800 & 46800 \\
\hline Sampling period & $1890-2011$ & $1973-2009$ & $1973-2009$ \\
\hline $\begin{array}{l}\text { Total amount of } \\
\text { nitrate analyses } \\
\text { from oxic } \\
\text { groundwater }\end{array}$ & 11518 & $194^{1}$ & $5321^{2}$ \\
\hline
\end{tabular}

\begin{tabular}{llll}
\hline $\begin{array}{l}\text { Sampling period } \\
\text { of oxic analyses }\end{array}$ & $1967-2011$ & $1997-2006^{1}$ & $1988-2009^{2}$ \\
\hline $\begin{array}{l}\text { Amount of oxic } \\
\text { monitoring } \\
\text { points }\end{array}$ & 3757 & $194^{1}$ & $152^{2}$ \\
\hline
\end{tabular}

$\begin{array}{llll}\text { Presentations } & \text { Fig. 2a } & \text { Fig. } 3 & \text { Fig. } 2 \mathrm{~b} \text { and } \mathrm{c}\end{array}$

Figs. 4 and 5

${ }^{1}$ Nitrate analyses used for trend analyses on a national scale. CFC dated oxic monitoring points.

2 Nitrate analyses used for trend analyses on an individual scale. CFC dated oxic monitoring points with stable oxic conditions and time series of more than $8 \mathrm{yr}$.

ses has been normal procedure over the last approximately $20 \mathrm{yr}$ in the Danish Groundwater Monitoring Programme. The sampling and the field analyses are performed according to Danish technical standards.

The redox condition of the groundwater is used to segregate the relevant subset of data used in this study where only data from the oxic zone are used. This subset of data from the oxic zone represents groundwater with a nitrate content mirroring the original nitrate leaching from the root zone. In oxic groundwater, nitrate is expected to act as an inert tracer due to the presence of oxygen and the generally low reactivity of organic matter below the root zone.

In this study the oxic zone is defined as follows:

$$
\begin{aligned}
& \text { - Nitrate }>1 \mathrm{mgl}^{-1}, \\
& \text { - Iron }<0.2 \mathrm{mgl}^{-1} \text {, and } \\
& \text { - Oxygen }>1 \mathrm{mgl}^{-1}
\end{aligned}
$$

\subsection{Nitrate concentrations used for trend analyses on a national scale}

Only nitrate concentrations from the Danish Groundwater Monitoring Programme are used in the national trend analysis presented in Fig. 3. Details about the purpose, construction and hydro-geological conditions of the sites in the Danish Groundwater Monitoring Programme can be found in Jørgensen and Stockmarr (2009) and Hansen et al. (2011). 


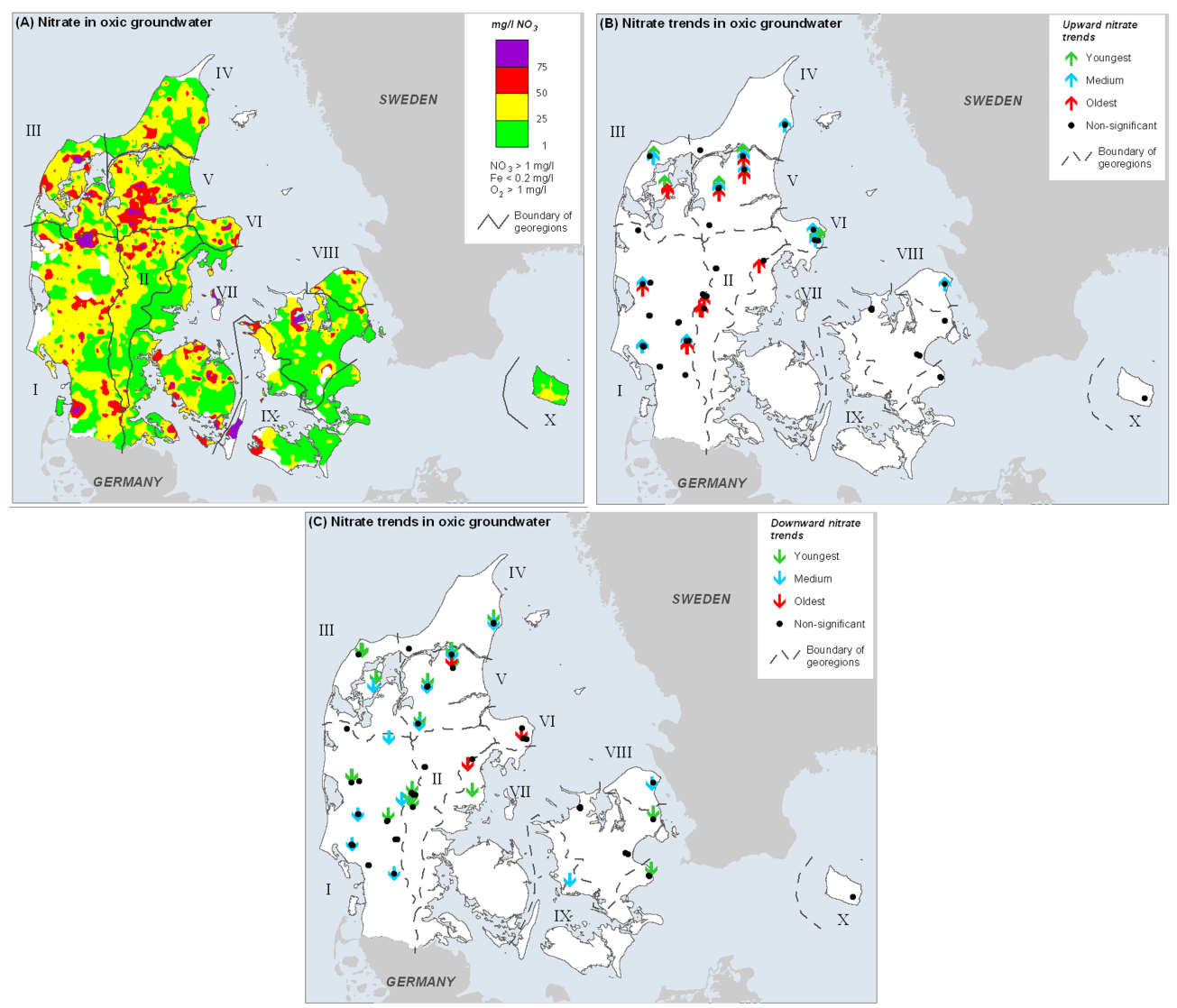

Fig. 2. (A) Interpolated geographic distribution of nitrate concentrations in oxic groundwater in Denmark based on 3757 analyses performed from 1890 to 2010. Average values from each measuring point are used in the interpolation. Shown are also 10 different geo-regions. (B, C) Geographic distribution of nitrate trends determined in 152 oxic CFC-dated groundwater monitoring points sampled from 1988 to 2009. A downward nitrate trend represents a negative slope of the linear regression line of nitrate versus sampling year for each groundwater monitoring point, while an upward trend shows a positive slope. The upward and downward nitrate trends are statistically significant with a $95 \%$ confidence level. Statistically non-significant nitrate trends are also shown.

The programme covers 74 clustered catchments covering areas of 5 to $50 \mathrm{~km}^{2}$, each containing about 25 wells. The groundwater monitoring sites are affected by different types of (1) agricultural land uses, (2) geological settings, (3) hydrological conditions, (4) depths, and (5) groundwater redox conditions. The entire Danish monitoring dataset includes approximately 46800 nitrate analyses from 1500 groundwater monitoring points (Table 1). Only a subset of the complete dataset is used in the trend analyses in the present study.

The nitrate concentrations used for trend analyses on a national scale originate from 194 groundwater monitoring points with oxic groundwater where the groundwater recharge age has also been determined using the CFC (chlorofluorocarbon) method, typically once during the period 1997-2006. The groundwater recharge age determination allows the comparison of long-term changes in $\mathrm{N}$ surplus in agriculture with changes in oxic groundwater quality (Hinsby et al., 2008). The CFC analyses were performed according to the procedure of Laier (2005) as described in Hansen et al. (2011).

\subsection{Nitrate concentrations used for trend analyses on an individual scale}

Nitrate concentrations from the Danish Groundwater Monitoring Programme are also used in the trend analyses for individual point measurements depicted in Figs. 2b, c, 4 and 5.

The nitrate concentrations used for trend analyses for individual point measurements comprise 5321 nitrate analyses from 152 monitoring points sampled from 1988-2009 where the groundwater (1) had stable oxic conditions, (2) was CFCdated and (3) had time series of between 8 and $20 \mathrm{yr}$ with approximately one nitrate analysis per year (Table 1).

The groundwater chemistry data from the Danish Groundwater Monitoring Programme used in the trend analyses were downloaded from the Danish national geo-database (JUPITER) in October 2009 (www.geus.dk). 


\subsection{Nitrogen surpluses in agriculture}

The annual national surplus of $\mathrm{N}$ in agriculture is estimated as the difference between inputs (synthetic fertilizer, import of animal feed, organic waste products, net atmospheric deposition and fixation) and outputs (export of plant and animal products). The annual national $\mathrm{N}$ surplus presented in this paper is estimated based on information from Statistics Denmark (2010) and Dalgaard and Kyllingsbæk (2003) on these entries in the budget.

The surplus of nutrients, and especially $\mathrm{N}$, is regarded as the best overall environmental indicator for the changes in the agricultural impact on the environment over a certain time period (European Environmental Agency, 2005). The surplus represents the amount of $\mathrm{N}$ pooled in the soil, or not being used up by the production system, and which is therefore at risk of being lost to the environment (Dalgaard et al., 2011b; Hansen et al., 2000). The N surplus can be described as the sum of nitrate leaching ( $\mathrm{N}_{\text {leaching }}$ ), ammonia emission $\left(\mathrm{N}_{\text {emission }}\right)$, denitrification, and accumulation of $\mathrm{N}$ in the soil $\left(\mathrm{N}_{\text {accumulation }}\right)$ according to the definition of Dalgaard et al. (2011b), and formulated in Eq. (1):

$$
\mathrm{N}_{\text {surplus }}=\mathrm{N}_{\text {leaching }}+\mathrm{N}_{\text {emission }}+\mathrm{N}_{\text {denitrification }}+\mathrm{N}_{\text {accumulation }}
$$

In this paper, the regional $\mathrm{N}$ surpluses for each of the ten Danish geo-regions shown in Fig. 2 are estimated from the annual, national $\mathrm{N}$ surplus as accounted for by Hansen et al. (2011). For each geo-region and for each year from 1950 to 2007, the livestock units are sourced from national county statistics and accord with the linear relationship between livestock units and $\mathrm{N}$ surplus identified by Dalgaard et al. (2011b). The annual, national $\mathrm{N}$ surplus values are apportioned according to the number of livestock units in each georegion. In this way an approximate $\mathrm{N}$ surplus in each georegion is found. However, this might differ from the "true" $\mathrm{N}$ surplus in the geo-region, for example, due to different distributions of livestock and individual farming practices in each region.

\subsection{Water balances}

Water balance components were estimated by the national water resources model called the DK model (Højberg et al., 2012), which is a coupled surface-groundwater model with a horizontal discretization of $500 \times 500 \mathrm{~m}$ covering the entire country with the exception of minor islands. The model is set up in the MIKE SHE/MIKE11 model system, where the unsaturated zone is described by a water balance module, while the saturated zone is described by a comprehensive threedimensional groundwater component to estimate recharge to and hydraulic heads in different geological layers. Streamaquifer interaction and stream flow-routing are described by MIKE11. The model is constructed on the basis of comprehensive national databases on geology, soil, topography, river systems, climate and hydrology and has recently been up- dated to include hydrological interpretations from regionaland local-scale hydrological models.

Daily groundwater recharge values $\left(\mathrm{mmday}^{-1}\right)$ are extracted from the model simulations with MIKE SHE and represent 10-yr average values for the period 1998-2007. For each of the 152 groundwater monitoring points, a groundwater recharge value is found from the $500 \times 500 \mathrm{~m}$ cell from the groundwater model where the well is situated.

\subsection{Statistical methods}

\subsubsection{Gridding of nitrate concentrations}

The data on the nitrate concentration map in Fig. 2 were interpolated using the kriging method of the Surfer programme (Surfer, 2002). A semi-variogram was fitted with an exponential function. The search radius of $10 \mathrm{~km}$ and a cell size of $2500 \mathrm{~m}$ were used.

\subsubsection{Nitrate trend analyses}

Determination of nitrate trends was achieved using the SAS software system (SAS, 2008) as described in Hansen et al. (2011).

\section{Results}

\subsection{Geographic assessment of nitrate in oxic groundwater}

Figure 2a shows that nitrate has been found in the oxic part of the groundwater throughout Denmark, with concentrations of up to $360 \mathrm{mg} \mathrm{l}^{-1}$ when using average nitrate concentrations based on all available data from oxic groundwater from 1967-2011. Nitrate concentrations of $25 \mathrm{mg} \mathrm{l}^{-1}$ are exceeded in $54 \%$ of the datasets, corresponding to $55 \%$ of the total area of Denmark, and nitrate concentrations of $50 \mathrm{mg} \mathrm{l}^{-1}$ are exceeded in $24 \%$ of the dataset, equivalent to $10 \%$ of the total area of Denmark (Fig. 2a). However, if we consider only data from the Danish Groundwater Monitoring Programme sampled from 1988-2009 and representing ages up to maximum $50 \mathrm{yr}$, then the nitrate concentrations of $25 \mathrm{mg} \mathrm{l}^{-1}$ and $50 \mathrm{mg} \mathrm{l}^{-1}$ are exceeded in $79 \%$ and $48 \%$ of the 152 oxic monitoring points, respectively. The nitrate concentrations in the oxic groundwater data from the Danish Groundwater Monitoring Programme are higher than the concentrations that appear from the data shown in Fig. 2a, because the oxic data from the Danish Groundwater Monitoring Programme on average represent younger and more nitrate-polluted groundwater.

However, Fig. 2a shows a regional pattern of nitrate concentrations where the oxic groundwater is most severely polluted with nitrate in northern and western Denmark (georegions I, II, III, IV, and V), while eastern Denmark (georegions VI, VII, VIII, IX, and X) is less polluted with nitrate. 


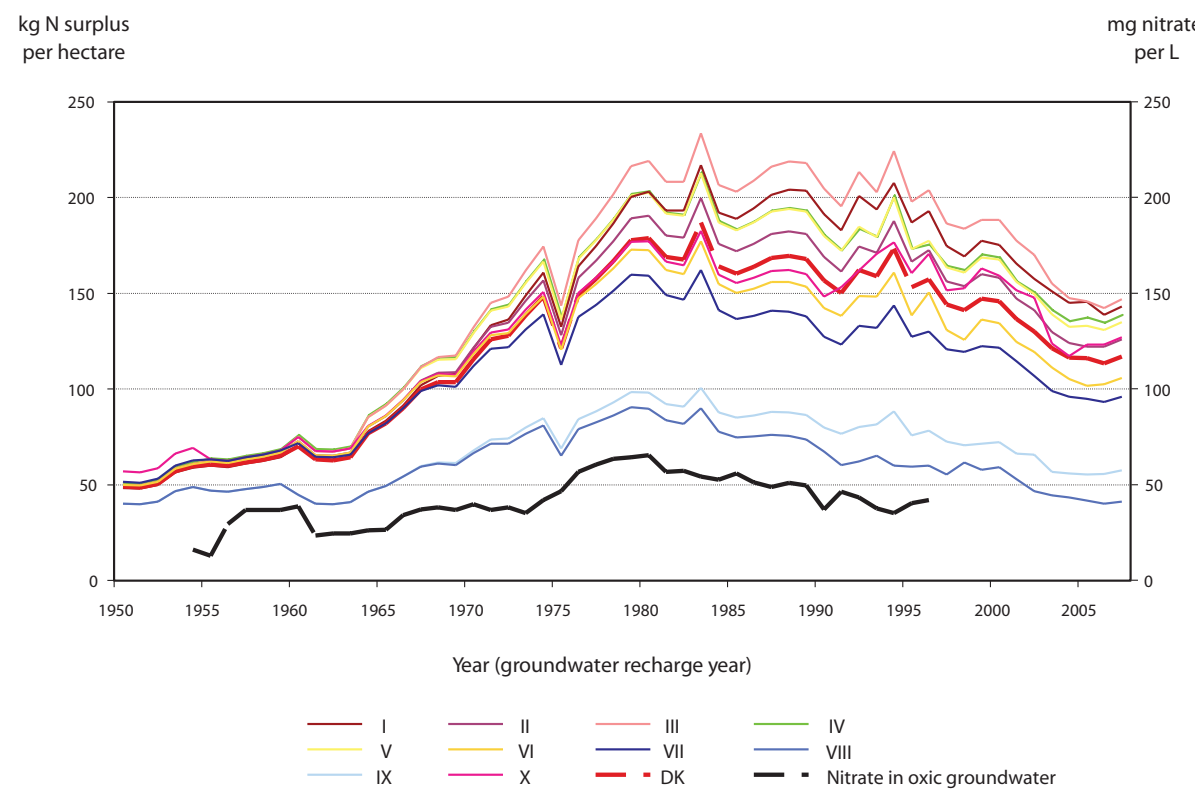

Fig. 3. Time series of agricultural $\mathrm{N}$ surplus in 10 different geo-regions of Denmark, and nitrate in oxic groundwater versus recharge age (CFC-age) at an annual mean level. The nitrate concentrations in oxic groundwater are shown as a 5-yr moving average curve. The location of the 10 geo-regions is seen in Fig. 2a.

An examination of the geographic distribution of the upward and downward nitrate trends and non-significant nitrate trends in the 152 oxic groundwater monitoring points sampled from 1989-2009 reveals no obvious regional pattern (see Fig. $2 \mathrm{~b}$ and c). However, the most pronounced downward nitrate trends seem to be where the concentrations of nitrate in the groundwater are highest in northern and western Denmark (geo-regions I, II, III, IV, and V).

The occurrence of oxic groundwater with high concentrations of nitrate is most likely due to a combination of (1) insufficient protection of the aquifer from overlying clay layers, (2) a low nitrate reduction capacity of the sediments of the aquifer, e.g. low content of potential reduction agents like pyrite, $\mathrm{Fe}^{\mathrm{II}}$ and organic matter, (3) a high groundwater recharge, and (4) high nitrate leaching from agricultural land. Widespread pollution of groundwater with nitrate is therefore likely to be found where the redox interface has penetrated deeply into the soil layers (see Fig. 1.).

\subsection{Regional trends of $\mathrm{N}$ surpluses and nitrate in oxic groundwater}

Denmark is divided into ten different geo-regions according to Kronvang et al.(2008), and regional $\mathrm{N}$ balances have been calculated for each geo-region as seen in Fig. 2a. The regional balances are shown together with the national $\mathrm{N}$ balance in Fig. 3 and Table 2. All the ten different regional N balances have the same overall temporal pattern as the national $\mathrm{N}$ balance with minimums and maximums occurring at the same time. However, the regional $\mathrm{N}$ balances are stag- gered so that northern and western Jutland (geo-regions I, II, III, IV and V) have a higher and eastern and southern Denmark (geo-regions VI, VII, VIII, IX, X) have a lower N surplus level than the national average $\mathrm{N}$ surplus level.

The higher $\mathrm{N}$ surplus level in northern and western Jutland and lower N-surplus level in eastern and southern Denmark are in accordance with the geographic pattern of the nitrate concentration levels in oxic groundwater seen in Fig. 2a. There are many reasons for the geographic distribution of nitrate in oxic groundwater where the $\mathrm{N}$ surplus might be one of them, but other reasons might be the geographic distribution of soil types, land use, nitrate reduction capacity of the sediments, precipitation and groundwater recharge in Denmark.

In almost every geo-region in Denmark, the N-surpluses were approximately $50 \mathrm{~kg} \mathrm{Nha}^{-1} \mathrm{yr}^{-1}$ in 1950 , where the country as a whole was characterized by mixed farming and the livestock was distributed evenly across all regions (Dalgaard and Kyllingsbæk, 2003). Over the following $30 \mathrm{yr}$, $\mathrm{N}$ surpluses rose dramatically in every geo-region and they reached a maximum around 1980 where they ranged from $234 \mathrm{~kg} \mathrm{~N} \mathrm{ha}^{-1} \mathrm{yr}^{-1}$ in Thy (geo-region III) in northern Jutland to $91 \mathrm{~kg} \mathrm{Nha}^{-1} \mathrm{yr}^{-1}$ in North Zealand (geo-region VIII) in the eastern part of Denmark. Since 1980, the N surpluses have decreased by $30-55 \%$ in all Danish georegions. The national average $\mathrm{N}$ surplus reduction since 1980 is about $37 \%$, and the national average $\mathrm{N}$ surplus was $117 \mathrm{~kg} \mathrm{~N} \mathrm{ha}^{-1} \mathrm{yr}^{-1}$ in 2007 (see Table 2).

The trends in the regional $\mathrm{N}$ surpluses and the national $\mathrm{N}$ surpluses both show the same fluctuations as the nitrate 
Table 2. Distribution statistics of annual agricultural N surpluses from 1950 to 2007 in 10 different geo-regions of Denmark, and in Denmark as a whole.

\begin{tabular}{|c|c|c|c|c|c|c|c|}
\hline $\begin{array}{l}\text { Geo- } \\
\text { region No. }\end{array}$ & $\begin{array}{l}\text { Geo-region } \\
\text { Name }\end{array}$ & 1950 & Max & 2007 & $\begin{array}{r}\text { Mean } \\
1950-2007\end{array}$ & $\begin{array}{r}\text { Increase } \\
1950-2007\end{array}$ & $\begin{array}{l}\text { Reduction } \\
1980-2007\end{array}$ \\
\hline I & West Jutland & 48 & 217 & 143 & 139 & $95(198 \%)$ & $74(34 \%)$ \\
\hline II & Mid Jutland & 50 & 200 & 126 & 130 & $76(152 \%)$ & $74(37 \%)$ \\
\hline III & Thy & 50 & 234 & 147 & 148 & $97(194 \%)$ & $87(37 \%)$ \\
\hline IV & North Jutland & 50 & 212 & 138 & 137 & $88(176 \%)$ & $74(34 \%)$ \\
\hline V & Himmerland & 50 & 213 & 135 & 137 & $85(170 \%)$ & $78(37 \%)$ \\
\hline VI & Djursland & 50 & 177 & 106 & 117 & $56(112 \%)$ & $71(40 \%)$ \\
\hline VII & East Denmark & 51 & 162 & 96 & 117 & $45(88 \%)$ & $66(41 \%)$ \\
\hline VIII & North Zealand & 40 & 91 & 41 & 60 & $1(3 \%)$ & $50(55 \%)$ \\
\hline IX & South Zealand & 40 & 101 & 58 & 68 & $17(43 \%)$ & $43(42 \%)$ \\
\hline $\mathrm{X}$ & Bornholm & 57 & 183 & 127 & 125 & $70(123 \%)$ & $56(30 \%)$ \\
\hline DK & Denmark (in total) & 49 & 187 & 117 & 122 & $68(139 \%)$ & $70(37 \%)$ \\
\hline
\end{tabular}

concentration trends in oxic groundwater at the national level (Fig. 3). The nitrate concentrations in oxic groundwater are shown as a 5-yr moving average curve based on groundwater measurements (nitrate analyses and CFC dating) performed from 1997-2006 representing groundwater recharged from 1954-1996 (Fig. 3). This phenomenon is elucidated in detail in Hansen et al. (2011), who report a statistically significant nitrate trend reversal in oxic groundwater around 1980. Figure 3 also shows that the increase in $\mathrm{N}$ surpluses in agriculture in the 1950s, 1960s and 1970s levelled out after 1980.

\subsection{Nitrate trends in oxic groundwater}

The nitrate trends of the time series of nitrate concentrations in the 152 oxic groundwater monitoring points were assessed by linear regression, as described in detail in Hansen et al. (2011). The slopes of each of these 152 linear regression lines represent the nitrate trend or the changes in nitrate shown in mg nitrate $\mathrm{l}^{-1} \mathrm{yr}^{-1}$. Thus, negative slopes represent downward trends, while positive slopes represent upward nitrate trends. In Fig. 4, the upward and downward nitrate trends are illustrated according to the age of the groundwater determined with the CFC method and the data are divided into three age groups.

The general national nitrate trends (Fig. 3) show a trend reversal around 1980; however, the nitrate trends from the individual monitoring points show a more complex picture as seen in Fig. 4 and Table 3.

Ninety-four of the 152 oxic groundwater monitoring points have statistically significant $(p<0.05)$ nitrate trends, of which 50 are upward and 44 are downward. The remaining 58 monitoring points have non-significant nitrate trends.

As far as the upward nitrate trends are concerned, $20 \%$ are in the youngest groundwater $(<15 \mathrm{yr})$, while $42 \%$ are in the oldest groundwater $(25-50 \mathrm{yr})$. The reverse pattern is found for the downward nitrate trends where $54 \%$ are in the youngest groundwater and only $7 \%$ in the oldest. Fur-

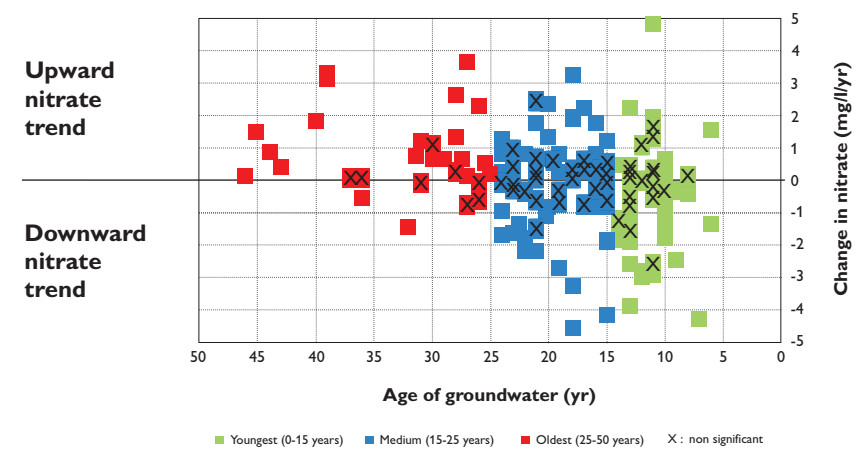

Fig. 4. Three age groups of upward and downward nitrate trends in oxic groundwater at a monitoring point level for 152 oxic CFCdated groundwater measuring points sampled from 1988 to 2009. The change in nitrate $\left(\mathrm{mg} \mathrm{l}^{-1} \mathrm{yr}^{-1}\right)$ is equivalent to the slope of the linear regression lines of nitrate versus sampling year for each groundwater monitoring point. The age of the groundwater is determined with the CFC method.

thermore, these findings are challenged; according to Fig. 4 for the oldest groundwater, upward nitrate trends can be as high as $4 \mathrm{mg}$ nitrate per 1 per year. In addition, the youngest groundwater can have downward nitrate trends up to almost $5 \mathrm{mg}$ nitrate per 1 per year.

The rate of changes in the nitrate concentrations $\left(\mathrm{mg} \mathrm{l}^{-1} \mathrm{yr}^{-1}\right)$ is highest in the groundwater monitoring points with the highest concentrations, which is both reflected in the significant upward and downward nitrate trends and in the non-significant nitrate trends (see Fig. 5a). Sixtyfour per cent of the downward nitrate trends have mean nitrate concentrations above $50 \mathrm{mg} \mathrm{l}^{-1}$ as opposed to only $38 \%$ of the upward nitrate trends. These findings are in line with the indications in Fig. 2 that the largest number of downward nitrate trends is found where the mean nitrate concentrations in groundwater are highest, i.e. in the northern and western parts (geo-regions I, II, III, IV, and V). 
Table 3. Amount (\%) of statistically significant upward, statistically significant downward and non-significant nitrate trends in 152 oxic CFCdated groundwater monitoring points with a $95 \%$ confidence level. The nitrate trends are grouped according to (1) groundwater recharge age, (2) the average nitrate concentrations in groundwater, (3) the annual groundwater recharge, and (4) the N load to groundwater.

\begin{tabular}{|c|c|c|c|c|c|}
\hline & & Upward & Downward & Non significant & Total \\
\hline Total & & $50(100 \%)$ & $44(100 \%)$ & $58(100 \%)$ & $152(100 \%)$ \\
\hline \multirow{3}{*}{ Recharge age (yr) } & $<15$ & $10(20 \%)$ & $24(54 \%)$ & $21(36 \%)$ & $55(36 \%)$ \\
\hline & $15-25$ & $19(38 \%)$ & $17(39 \%)$ & $28(48 \%)$ & $64(42 \%)$ \\
\hline & $25-50$ & $21(42 \%)$ & $3(7 \%)$ & $9(16 \%)$ & $33(22 \%)$ \\
\hline \multirow{3}{*}{ Nitrate in groundwater $\left(\mathrm{mg} \mathrm{l}^{-1}\right)$} & $1-10$ & $6(12 \%)$ & $0(0 \%)$ & $5(9 \%)$ & $11(7 \%)$ \\
\hline & $10-50$ & $25(50 \%)$ & $16(36 \%)$ & $27(47 \%)$ & $68(45 \%)$ \\
\hline & $\geq 50$ & $19(38 \%)$ & $28(64 \%)$ & $26(44 \%)$ & $73(48 \%)$ \\
\hline \multirow{3}{*}{ Groundwater recharge $\left(\mathrm{mm} \mathrm{yr}^{-1}\right)$} & $<400$ & $19(38 \%)$ & $15(34 \%)$ & $23(40 \%)$ & $57(38 \%)$ \\
\hline & $400-600$ & $24(48 \%)$ & $23(52 \%)$ & $21(37 \%)$ & $68(45 \%)$ \\
\hline & $600-750$ & $7(14 \%)$ & $6(14 \%)$ & $13(23 \%)$ & $26(17 \%)$ \\
\hline \multirow{3}{*}{$\mathrm{N}$ load to groundwater $\left(\mathrm{kg} \mathrm{Nha}^{-1} \mathrm{yr}^{-1}\right)$} & $<25$ & $18(36 \%)$ & $15(34 \%)$ & $21(37 \%)$ & $54(36 \%)$ \\
\hline & $25-75$ & $25(50 \%)$ & $18(41 \%)$ & $23(40 \%)$ & $66(44 \%)$ \\
\hline & $\geq 75$ & $7(14 \%)$ & $11(25 \%)$ & $13(23 \%)$ & $31(20 \%)$ \\
\hline
\end{tabular}

As far as groundwater recharge is concerned, most of the upward and downward nitrate trends (approx. 50\%) are found at an annual mean recharge level of 400-600 $\mathrm{mm} \mathrm{yr}^{-1}$, and no obvious differences can be seen between the upward and downward nitrate trends (Fig. 5b).

The $\mathrm{N}$ load to groundwater is calculated by multiplying the nitrate concentrations and the groundwater recharge. Twenty-five per cent of the groundwater monitoring points with downward nitrate trends have a high $\mathrm{N}$ load (>75 $\mathrm{kg} \mathrm{Nha}^{-1} \mathrm{yr}^{-1}$ ) to the groundwater compared with only $11 \%$ of the upward nitrate trends. This finding seems to be due to the nitrate concentration levels rather than to the local mean level of the groundwater recharge in Denmark.

\section{Discussion and conclusions}

Denmark has seen its farming sector develop a high livestock density due notably to the increase in pig production and the concentration of dairy farming in western Denmark over the last century (Dalgaard and Kyllingsbæk, 2003). Farms with a high livestock density have accomplished larger reductions in N surplus between the years 1990 and 2008 than farms with cash crop production using synthetic fertilizers and little livestock manure (Dalgaard et al., 2012). These circumstances can explain the findings in the present study where there seems to be consistency between a high $\mathrm{N}$ surplus in agriculture, high concentrations of nitrate in groundwater and the most pronounced downward nitrate trends in groundwater in northern and western parts of Denmark. In absolute values, the reduction in $\mathrm{N}$ surplus from 1980-2007 in these regions is also highest $\left(74-87 \mathrm{~kg} \mathrm{~N} \mathrm{ha}^{-1} \mathrm{yr}^{-1}\right.$ ); however, the relative reduction in $\mathrm{N}$ surplus is lower (34-37\%) than in eastern and southern Denmark (40-55\%).
A clear indication of an effect of reduced $\mathrm{N}$ surplus in agriculture on groundwater nitrate concentrations in Denmark is seen in the age of the groundwater recharge relating to the upward and downward nitrate trends. Here $20 \%$ of the youngest ( $0-15 \mathrm{yr}$ old) and $42 \%$ of the oldest (25-50 yr old) groundwater display upward nitrate trends, while the opposite pattern is seen for the downward nitrate trends where $54 \%$ can be found in the youngest and $7 \%$ are in the oldest groundwater.

Mean nitrate concentrations above $50 \mathrm{mg} \mathrm{l}^{-1}$ are seen in $64 \%$ of the downward nitrate trends in oxic groundwater, but only in $38 \%$ of the upward nitrate trends. The $\mathrm{N}$ load in groundwater is the amount of nitrogen being transported by the groundwater and which might eventually flow out into groundwater-dependent ecosystems. The geographical variation in nitrate concentrations in groundwater rather than the amount of groundwater recharge influences the distribution of the groundwater $\mathrm{N}$ load, and $25 \%$ of the groundwater monitoring points with downward nitrate trends have a high $\mathrm{N}$ load compared with only $11 \%$ of the upward nitrate trends.

Together with the findings in Hansen et al. (2011), this study demonstrates a clear relationship between changes in the $\mathrm{N}$ surplus in agriculture, both at national and regional level, and changes in the nitrate concentrations in oxic groundwater with the same synchronic temporal pattern and trend reversals around 1980. The change and the development in Danish agricultural management of $\mathrm{N}$ have been driven mainly by politically enforced regulations since 1985 , but also changes in the economic and technical conditions for farming with fluctuating product prices and revisions of the European agricultural policies have been instrumental in accomplishing these changes (Uthes et al., 2011; Happe et al., 2011). Regulations in agriculture have a significant impact 

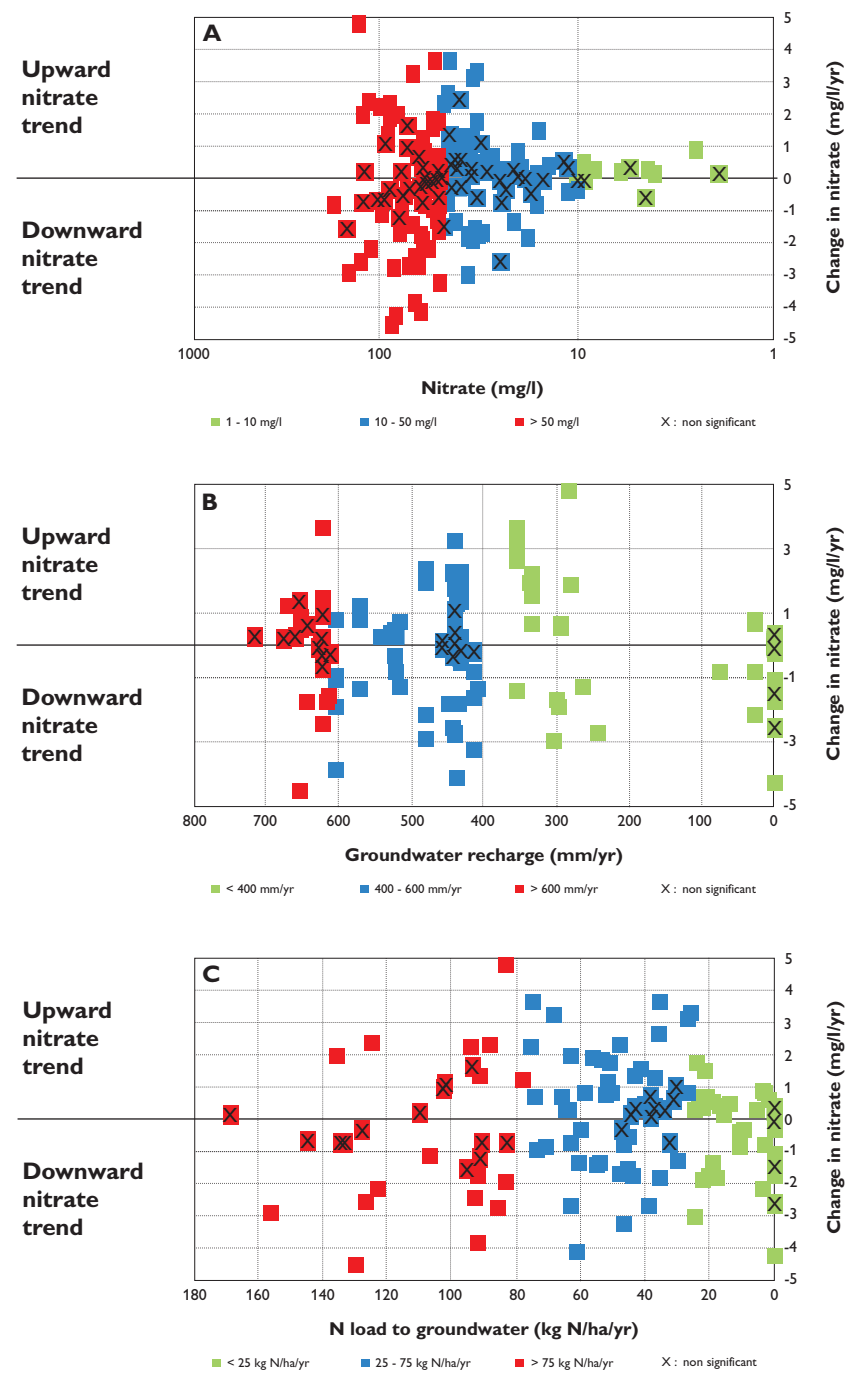

Fig. 5. Upward and downward nitrate trends in 152 oxic CFCdated groundwater monitoring points sampled from 1988 to 2009. (A) The mean nitrate concentration $\left(\mathrm{mgl}^{-1}\right)$ in each groundwater monitoring point. (B) The annual groundwater recharge $\left(\mathrm{mm} \mathrm{yr}^{-1}\right)$ in a circle of $1 \mathrm{~km}$ around each groundwater monitoring point. (C) the $\mathrm{N}$ load $\left(\mathrm{kg} \mathrm{Nha}^{-1} \mathrm{yr}^{-1}\right)$ to groundwater based on data shown in (A) and (B).

on the environment, as strongly indicated by the simultaneousness of the reduction in $\mathrm{N}$ surplus in agriculture and the reduced nitrate contamination of oxic groundwater. The experience from Denmark may provide inspiration for other countries where control of agricultural $\mathrm{N}$ losses is needed, as for example pointed out by Vitousek et al. (2009).

Of all the coastal waters in the world, those in Denmark are some of the most frequently exposed to hypoxia (Diaz and Rosenberg, 2008). The EU Water Framework Directive stipulates that Denmark reverses the upward trends in groundwater nitrate concentrations and complies with the groundwater quality standards of $50 \mathrm{mgl}^{-1}$ in certain ar- eas. Thus, the environmental goals in both Danish legislation and EU directives (The Nitrate Directive, 1991/696/EC; The Water Framework Directive, 2000/60/EC; and the Groundwater Directive, 2006/118/EF) have not yet been fully met. There is a need for more holistic future solutions to protect both groundwater, nature and the wider environment and to meet legislative requirements for a good chemical status of groundwater, and a good ecological status of the Danish estuaries and oceans is just one of the important goals.

The latest report from the Danish agricultural monitoring sites (Grant et al., 2011) shows a small increase in modelled nitrate leaching from 2003 to 2010 . The results from the individual trend analyses presented in this paper are based on groundwater data sampled from 1988-2009, and they represent groundwater recharged from 1952-2003 where the oldest monitored groundwater is about $46 \mathrm{yr}$ old and the youngest monitored groundwater is about $6 \mathrm{yr}$ old. Repetition of the nitrate trend analyses at five-year intervals based on dating of the groundwater recharge in the coming years and a longer time series of the nitrate analyses will shed more light on the groundwater effect of the evolution in nitrate leaching from Danish agriculture during the past $10 \mathrm{yr}$.

Acknowledgements. The presented groundwater data are collected as part of the governmentally supported Danish Environmental Monitoring Programme.

Edited by: H. van Grinsven

\section{References}

Aguilar, J. B., Orban, P., Dassargues, A., and Brouyère, S.: Identification of groundwater quality tends in a chalk aquifer threatened by intensive agriculture in Belgium, Hydrogeol. J., 15, 16151627, 2007.

Burow, K. R., Nolan, B. T., Rupert, M. G., and Dubrovsky, N. M.: Nitrate in Groundwater in the United States, 1991-2003, Environmental Science and Technology, 44, 4988-4997, 2010.

Dalgaard, T. and Kyllingsbæk, A.: Developments in the nitrogen surplus and the fossil energy use in Danish Agriculture during the 20th century, in: Advances in Ecological Sciences, edited by: Usó, J. L., Patten, B. C., and Brebbia, C. A., WIT Press Southampton, UK, 18, 669-678, 2003.

Dalgaard, T., Hutchings, N., Børgesen, C., Vinther, F. P., and Hansen, B.: How can nitrogen utilization in farming systems be optimized to minimize losses?, proceeding from ifs (International Fertiliser Society), 2011a.

Dalgaard, T., Hutchings, N., Dragosits, U., Olesen, J. E., Kjeldsen, C., Drouet, J.,L., and Cellier, P.: Effects of farm heterogeneity on modelling and upscaling of nitrogen losses and greenhouse gas emissions in agricultural landscapes, Environ. Pollut., 159, 3183-3192, 2011 b.

Dalgaard, T., Bienkowski, J. F., Bleeker, A., Drouet, J. L., Durand, P., Dragosits, U., Frumau, A., Hutchings, N. J., Kedziora, A., Magliulo, V., Olesen, J. E., Theobald, M. R., Maury, O., Akkal, N., and Cellier, P.: Farm nitrogen balances in six European agri- 
cultural landscapes - a method for farming system assessment, emission hotspot identification, and mitigation measure evaluation, Biogeosciences Discuss., 9, 8859-8904, doi:10.5194/bgd9-8859-2012, 2012.

Diaz, R. J. and Rosenberg, R.: Spreading Dead Zones and Consequences for Marine Ecosystems, Science, 321, 926-929, 2008.

Erisman, J.W., van Grinsven, H., Grizzetti, B., Bouraoui, F., Powlson, D., Sutton, M.A., Bleeker, A. Reis, S.: The European nitrogen problem in a global perspective, in: The European Nitrogen Assessment, edited by: Sutton, M., Howard, C. M., Erisman J. W., Billen, G., Bleeker, A., Grennfelt, P., Grinsven, H. V., and Grizzetti, B, Cambridge, 9-31, 2011.

Ernstsen, V.: Micro- and macro-geochemical environments of clayey till deposits.The Geological Society of America, 1999 Annual meeting and exposition, October 25-28 1999, Denver, USA, GSA Abstracts with programme, p. A450, 1999.

European Environmental Agency: Agriculture and environment in EU-15 - the IRENA indicator report, EEA Report No 6/2005 ISBN 92-9167-779-5, ISSN 1725-9177, EEA, Copenhagen, 2005.

Grant, R., Blicher-Mathiesen, G., Jensen, P. G., Hansen, B., and Thorling, L.: Landovervågningsoplande 2010, NOVANA, Aarhus Universitet, DCE - Nationalt Center for Miljø og Energi, - Videnskabelig rapport fra DCE - Nationalt Center for Miljø og Energi nr. 3, 130 pp., 2011.

Grizzetti, B., Bouraoui, F., Billen, G., van Grinsven, H., Cardoso, A. C., Thieu, V., Garnier, J., Curtis, C., Howarth, R., and Johnes, P.: Nitrogen as a threat to European water quality, in: The European Nitrogen Assessment, edited by: Sutton, M., Howard, C. M., Erisman, J. W., Billen, G., Bleeker, A., Grennfelt, P., Grinsven, H. V., and Grizzetti, B., Cambridge, 379-404, 2011.

Hansen, B. and Thorling, L.: Use of geochemistry in groundwater vulnerability mapping in Denmark, Geol. Surv. Den. Greenl., 15, 45-48, 2008.

Hansen, B., Kristensen, E. S., Grant, R., Høgh-Jensen, H., Simmelsgaard, S. E., and Olesen, J. E.: Nitrogen leaching from conventional versus organic farming systems - system modelling approach, Eur. J. Agron., 13, 65-82, 2000.

Hansen, B., Thorling, L., Dalgaard, T., and Erlandsen, M.: Trend Reversal of Nitrate in Danish Groundwater - a Reflection of Agricultural Practices and Nitrogen Surpluses since 1950, Environm. Sci. Technol., 45, 228-234, 2011.

Happe, K., Hutchings, N., Dalgaard, T., and Kellermann, K.: Modelling the interactions between regional farming structure, nitrogen losses and environmental regulation, Agr. Syst., 104, 282 291, 2011

Højberg, A. L., Troldborg, L., Stisen, S., Christensen, B. S. B., and Henriksen, H. J.: Stakeholder driven update and improvement of a national water resources model, Environ. Modell. Softw., submitted, 2012.

Hinsby, K.; Purtschert, R.; Edmunds, W.M:. Groundwater age and Quality, in: Groundwater Science and Policy - An International Overview, RSC Publishing, edited by: Quevauviller, P., Roy. Soc. Chem., Cambridge, 217-239, 2008.

Jørgensen, L. F. and Stockmarr, J.: Groundwater monitoring in Denmark: characteristics, perspectives and comparison with other countries, Hydrogeol. J., 17, 827-842, 2009.
Kronvang, B., Andersen, H. E., Børgensen, C., Dalgaard, T., Larsen, S. E., Bøgestrand, J., and Blicher-Mathiasen, G.: Effects of policy measures implemented in Denmark on nitrogen pollution of the aquatic environment, Environ. Sci. Policy, 11, 144-152, 2008.

Laier, T.: Nitrate monitoring and CFC-age dating of shallow groundwaters - an attempt to check the effect of restricted use of fertilizers, in: Nitrates in Groundwater, edited by: RazowskaJaworek, L. and Sadurski, A., International Associations of hydrogeologists selected papers, A. A. Balkema Publishers, Chapter 24, 2005.

OECD: Environmental Performance in Agriculture in OECD Counties since 1990, available at: www.oecd.org/tad/env/indicators (last access: November 2010), Paris, France, 2010.

Postma, D., Boesen, C., Kristiansen, H., and Larsen, F.: Nitrate Reduction in An Unconfined Sandy Aquifer - Water Chemistry, Reduction Processes, and Geochemical Modeling, Water Resour. Res., 27, 2027-2045, 1991.

Rockström, J., Steffen, W., Noone, K., Persson, Å., Chapin, F. S., Lambin, E. F., Lenton, T. M., Scheffer, M., Folke, C., Schellnhuber, H. J., Nykvist, B., de Wit, C. A., Hughes, T., van der Leeuw, S., Rodhe, H., Sörlin, S., Snyder, P. K., Costanza, R., Svedin, U., Falkenmark, M., Karlberg, L., Corell, R. W., Fabry, V. J., Hansen, J., Walker, B., Liverman, D., Richardsonm K., Crutzen, P., and Foley, J. A.: A safe operating space for humanity, Nature, 461, 472-475, 2009.

Rupert, M. G.: Decadal-Scale Changes of Nitrate in Groundwater of the United States, 1988-2004, September-October, J. Environ. Qual., 37, 240-248, 2008.

SAS: SAS/STAT 9.2; SAS Institute Inc., Cary, NC, 2008.

Statistics Denmark: National Statistical Database 2010 (Statistikbanken), Danmarks Statistik, København, 2010.

Surfer: Surfer 8, Counturing and 3D Surface Mapping for Scientists and Engineers, Golden Software, 2002.

Uthes S., Piorr, A., Zander, P., Kedziorac, A., Ungaro F., Dalgaard, T., Kjeldsen, C., Stolze, M., Moschitz, H., Schader, C., Happe, K., Sahrbacher, A., Damgaard, M., Sattler, C., Toussainta, V., Casini, L., and Müller, C.: Regional impacts of abolishing direct payments: and integrated analysis in four European regions, Agr. Syst., 104, 110-121, 2011.

van Grinsven, H. J. M., Rabl, A., and de Kok, T. M.: Estimation of incidence of social cost of colon cancer due to nitrate in drinking water in the EU: a tentative cost-benefit assessment, Environ. Health-Glob., 9, 58, doi:10.1186/1476-069X-9-58, 2010.

Visser, A., Broers, J., van der Grift, B., and Bierkens, M. F. P.: Demonstrating trend reversal of groundwater quality in relation to time of rechragae determined by ${ }^{3} \mathrm{H} /{ }^{3} \mathrm{He}$, Environ. Pollut., 148, 797-807, 2007.

Vitousek, P. M., Aber, J. D., Howarth, R. W., Likens, G. E., Matson, P. A., Schindler, D. W., Schlesinger, W. H., and Tilman, G.: Human alternation of the global nitrogen cycle: sources and consequences, Ecol. Appl., 7, 737-750, 1997.

Vitousek, P. M., Naylors, R., Crews, T., David, M. B., Drinkwater, L. E., Holland, E., Johnes, P. J., Katzenberger, J., Martinelli, L. A., Matson, P. A., Nziguheba, G., Ojima, D., Palm, C. A., Robertson, G. P., Sanchez, P. A., Townsend, A. R., and Zhang, F. S.: Nutrient imbalances in agricultural development, Science, 324, 1519-1520, 2009. 